\title{
Hepatita E - efectul asupra ficatului şi dincolo de acesta
}

\author{
Mihaela Cătălina Luca',2, Ioana-Alina Harja-Alexa', Ştefana Luca', \\ Georgiana Leonte-Enache ${ }^{1,2}$, Adelina Matei ${ }^{2}$, Andrei Vâță ${ }^{1,2}$ \\ ${ }^{1}$ Universitatea de Medicină şi Farmacie „Grigore T. Popa“ Iaşi, România \\ 2Spitalul Clinic de Boli Infecţioase „Sfânta Parascheva“ Iaşi, România
}

\begin{abstract}
REZUMAT
Introducere. Hepatita E este o infecţie acută a ficatului determinată de VHE şi reprezintă o problemă de sănătate publică la nivel internaţional comparabilă cu cea cauzată de alte boli transmisibile.

Scop. Scopul acestei lucrări este de a prezenta aspectele epidemiologice, clinico-biologice şi evolutive a infecţie determinată de VHC.

Material şi metodă. Anual, în întreaga lume, se înregistrează aproximativ 20 de milioane de infecţii cu VHE. Această boală are o răspândire universală, dar cu prevalenţe mai ridicate în Asia de Sud şi Est, unde se concentrează peste $60 \%$ dintre cazuri şi peste $65 \%$ dinrte decesele prin HVE. În România, incidenţa HVE în 2009 a fost de $12 \%$, datele privind frecvenţa infecţiilor fiind limitate la studiile de seroprevalenţă ale Ac IgG specifici anti-hepatită $\mathrm{E}$.

Rezultate. Transmiterea se realizează preponderent pe cale digestivă (în special prin apă contaminată), dar şi prin sânge, plasmă, transplant de organe. Perioada de incubaţie este cuprinsă între 21 şi 45 de zile. Boala debutează prin tulburări gastro-intestinale (sindrom dispeptic, greţuri, vărsături, inapetenţă), febră, sindrom pseudo-gripal, astenie, erupţie urticariană, scădere în greutate (între 2 şi 4 kg), durere sau disconfort abdominal la nivelul HD, deshidratare. În perioada de stare, bolnavul poate prezenta icter sclero-tegumentar, prurit tegumentar, steatoree, urini hipercrome. În plus faţă de manifestările clasice hepatice, VHE este responsabil pentru tulburări extrahepatice. Acestea includ o serie de sindroame neurologice, leziuni renale, pancreatită şi probleme hematologice. Tratamentul farmacologic al infecţiei cu HVE include Peg-Inf, Ribavirin şi, de asemenea, cei mai noi agenţi DAA.

Discuţii. La majoritatea pacienţilor, hepatita E provoacă o boală autolimitată care durează câteva săptămâni. Infecţia acută - în general asimptomatică - este determinată de genotipul 1, care afectează persoanele tinere, genotipurile 3 şi 4 afectând în general imunodeprimaţii. Infecţia cronică este determinată de genotipurile 3 şi 4 la imunodeprimaţi (transplantaţi, pacienţi HIV+, pacienţi hematologici), având incidenţă şi mortalitate inferioare. Evoluţia hepatitei virale $E$ poate fi severă şi fulminantă din cauza insuficienţei hepatice acute. Un vaccin recombinat aprobat şi efectuat în China în 2011 deschide perspective pentru măsurile de prevenire specifice în zonele identificate ca fiind expuse riscului, pentru a limita consecinţele infecţiei cu virusul hepatitei E în populaţia generală şi grupurile expuse.

Concluzii. Managementul hepatitei E implică atât terapia pacienţilor cronici sau imunodeprimaţi, cât şi terapia infecţiilor severe acute cu VHE şi a manifestărilor extrahepatice.
\end{abstract}

Cuvinte cheie: virus hepatitic E, genotipuri, imunodeprimaţi, tratament

Hepatita E este o infecție acută a ficatului cauzată de VHE, care determină simptome similare celor manifestate în infecții cu virusul hepatitic A, se transmite prin apă şi alimente contaminate şi reprezintă o problemă de sănătate publică la nivel internațional comparabilă cu cea cauzată de alte boli transmisibile.
Deşi nu determină uzual infecții cronice ale ficatului, foarte rar poate conduce la afecțiuni hepatice grave. Virusul hepatitei E (VHE) a fost descoperit în 1983 de către investigatorii unui focar de hepatită inexplicabilă la soldații sovietici din Afganistan (6). VHE este o particulă mică, fără anvelopă, care face parte din familia Hepeviridae. Geno- 
mul are o lungime de aproximativ 7.200 de baze, fiind o moleculă de ARN monocatenar (Fig. 1).

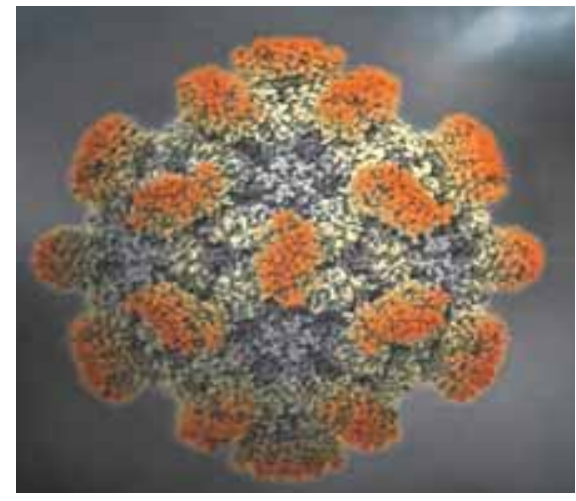

FIGURA 1. Virusul hepatitei $E$

Anual, în întreaga lume, se înregistrează aproximativ 20 de milioane de infecții cu VHE. Această boală are o răspândire universală, dar cu prevalențe mai ridicate în Asia de Sud şi Est, unde se concentrează peste $60 \%$ dintre cazuri şi peste $65 \%$ dintre decesele prin HVE. În Egipt, 50\% din populația de peste 5 ani este pozitivă serologic pentru HVE. Mortalitatea în populaţia generală variază între $0,5 \%$ şi $4 \%$ şi reprezintă $3,3 \%$ din rata totală a mortalității, însumând aproximativ 56.600 de decese, dar poate ajunge până la $25 \%$ în rândul gravidelor. Totodată, se estimează că există circa 3 milioane de cazuri simptomatice la nivel mondial.

Hepatita E este mai frecventă în zonele asiatice prin manifestarea endemică-epidemică. Infecția cu VHE a apărut şi în țările dezvoltate, unde circulaţia virusului nu era recunoscută (Franța, Germania, Anglia). Incidența infecției în UE este încă incertă din cauza limitării sistemelor de supraveghere, diferențelor de teste utilizate pentru a identifica etiologia hepatitelor, lipsei de informații. În Olanda,

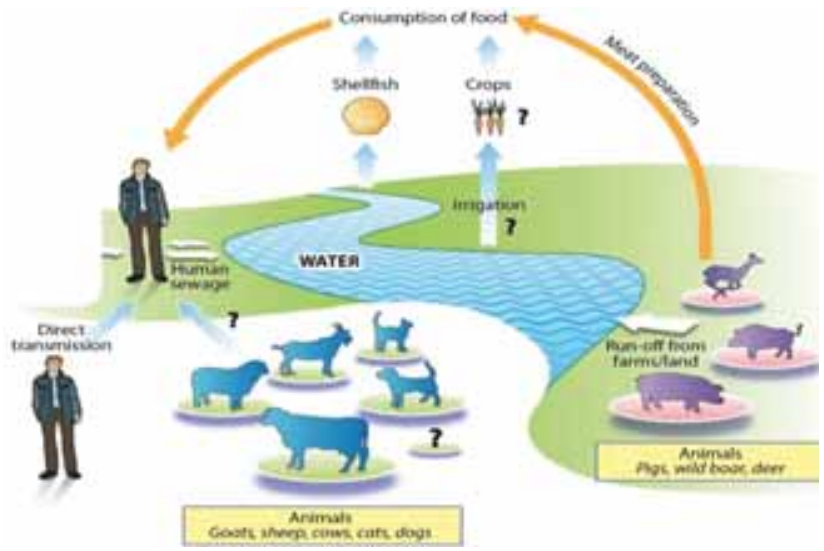

Germania şi Anglia s-a înregistrat recent o creştere a numărului de serologii pozitive la donatorii de sânge de vârstă tânără. 80\% cazuri de HVE au fost raportate în Germania, Franţa şi Anglia, prin implementarea sistemului de supraveghere a acestei infecții începând cu anul 2005 (7).

Proporţia cazurilor la pacienții de peste 50 de ani a crescut de la 30-45\% în perioada 2005-2008 la peste $60 \%$ în 2013-2015, fapt ce evidențiază evoluția dinamicii acestui fenomen epidemiologic emergent. A fost monitorizată cu o scădere a incidenței cazurilor de la $80 \%$ în 2005 la 55\% în 2015. Numărul de decese a crescut de la 0 - 1 cazuri pe an în perioada 2005-2008 la 4-8 cazuri pe an în 2012-2015.

În România, incidența HVE în 2009 a fost de $12 \%$, datele privind frecvența infecțiilor fiind limitate la studiile de seroprevalență ale Ac IgG specifici anti-hepatită E. Într-un raport al rezultatelor unui studiu efectuat asupra studenţilor şi personalului medical, prevalența acestor anticorpi a fost de $12,5 \%$ şi respectiv $14 \%$ (1).

Transmiterea se realizează preponderent pe cale digestivă (în special prin apă contaminată), dar şi prin sânge, plasmă, transplant de organe. Numărul de focare a crescut de la $0-3$ pe an în perioada 2005-2010 la 6 în 2014 şi 9 în 2015 până la 47 de focare în anul 2017. Deşi era considerată iniţial ca limitată la om, infecția cu virusul hepatitei E nu se limitează la răspândirea de la om la om, ci se produce şi între animale şi, mai important, ca răspândire zoonotică de la animale la oameni (Fig. 2).

Deşi prezintă un singur serotip există patru genotipuri majore VHE (1-4). Genotipul 3 predomină în țările dezvoltate, cu transmitere zoonotică şi legată în principal de consumul de carne de porc, dar şi de mistreț, cerb sau crustacee.

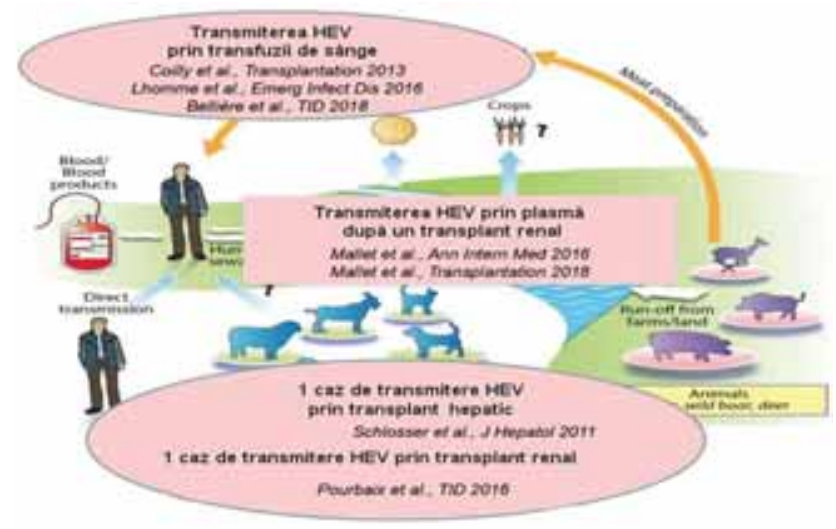

FIGURA 2. Răspândire zoonotică de la animale la oameni (Kamar et la. Lancet 2012) 


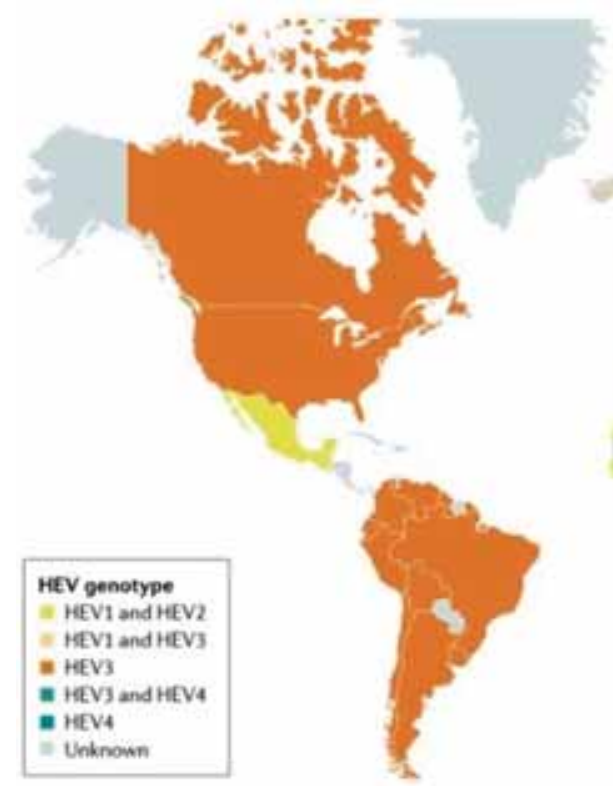

Kamar, N ot al (2017) Hepatitis E virus infection Nat. Rev. Dis. Primers doi $10,1038 / n$ rdp 2017.88

FIGURA 3. Implicarea clinică a celor 4 genotipuri

În Europa predomină genotipul 3 şi 4, iar cele cazurile asociate cu călătoriile în zonele endemice actuale sunt determinate de genotipurile 1, 2 şi 4 . Cele 4 genotipuri de VHE au implicare clinică diferită (Fig. 3).

La majoritatea pacienților, hepatita E provoacă o boală autolimitată care durează câteva săptămâni. Infecția acută - în general asimptomatică - este determinată de genotipul 1, care afectează persoanele tinere în timpul sarcinii, genotipurile 3 şi 4 afectând în general imunodeprimații. După o perioadă de incubație de 2 până la 6 săptămâni, apar simptome de hepatită (14). Mortalitatea excesivă se observă la femeile gravide şi la persoanele cu afecțiuni hepatice cronice, forma fulminantă pe sarcină fiind determinată preponderent de genotipul 1 şi având mortalitate de peste $25 \%$.
Infecția cronică este determinată de genotipurile 3 şi 4 la imunodeprimați (transplantați, pacienți HIV+, pacienți hematologici), având incidență şi mortalitate inferioare. Forma cronică este definită prin persistența replicării virale la 3 luni de la momentul infecției (Tabelul 1). Infecția cronică cu genotipurile 1 şi 2 nu a fost documentată, deşi au fost efectuate studii în acest sens. Într-un studiu recent efectuat la 205 de pacienţi cu transplant renal din India, Naik şi colegii nu au găsit nici o dovadă de infecție cronică cu HVE într-o zonă cu hiperendemicitate a genotipului 1 (7).

Totuşi, majoritatea cazurilor de hepatită E sunt asimptomatice. Perioada de incubație este cuprinsă între 21 şi 45 de zile. Boala debutează prin tulburări gastro-intestinale (sindrom dispeptic, grețuri,

TABELUL 1. Infecția cronică cu VHE

\begin{tabular}{|l|l|l|l|}
\hline & GENOT1P 1 & GEN0T1P 3 & GENOT1P4 \\
\hline \multirow{4}{*}{$\begin{array}{l}\text { INSUFICIENȚ̆ } \\
\text { HEPATICĂ ACUTĂ }\end{array}$} & $\bullet$ Apare pe sarcină & $\bullet$ Studii de cohortă & $\bullet$ Studiu China \\
\cline { 2 - 4 } & $\bullet$ Mortalitate de până 25\% & $\bullet$ Scoția 2,5\% HEV, fără decese & $\bullet$ Incidență 4,1\% \\
\cline { 2 - 4 } & & $\bullet$ Germania 10\% HEV, 1 deces & $\bullet$ Mortalitate 2,2\% \\
\hline \multirow{2}{*}{$\begin{array}{l}\text { INSUFICIENȚ̆ } \\
\text { HEPATICĂ CRONICĂ } \\
\text { DECOMPENSATĂ }\end{array}$} & $\bullet$ Studii de cohortă & $\bullet$ Fără decese pe sarcină & $\bullet$ Fără decese pe sarcină \\
\cline { 2 - 4 } & $\bullet$ Mortalitate de până 70\% & $\bullet 2,9 \%$ HEV & $\bullet$ Incidență 9\% \\
\hline & $\begin{array}{l}\text { Rein et al Hepatology 2012 } \\
\text { Kamar et al Lancet 2012 } \\
\text { Gumar Acharya J Hepatol 2007 }\end{array}$ & $\begin{array}{l}\text { Crossan et al WJH 2014 } \\
\text { Manka et al Clin GastroHepatol } 2015 \\
\text { Blascoe Perri et al APT 2015 }\end{array}$ & L Mortalitate 9\% \\
\hline
\end{tabular}


vărsături, inapetență), febră, sindrom pseudo-gripal, astenie, erupție urticariană, scădere în greutate (între 2 şi $4 \mathrm{~kg}$ ), durere sau disconfort abdominal la nivelul hipocondrului drept, deshidratare. În perioada de stare, bolnavul poate prezenta icter sclerotegumentar, prurit tegumentar, steatoree, urini hipercrome. Icterul apare la aproximativ $75 \%$ dintre pacienți. Alte simptome comune includ greață, febră, stare generală de rău, artralgii, vărsături, diaree şi durere abdominală. Nivelul ALT este de obicei între 1.000 şi 3.000 UI / 1. La majoritatea pacienților, recuperarea simptomatică şi biochimică se produce în decurs de 4 până la 6 săptămâni. Istoricul natural şi prognosticul sunt diferite: pacienții care suferă de afecțiuni hepatice cronice prezintă un prognostic nefavorabil, iar persoanele care sunt imunosupresate dezvoltă adesea infecții cronice (Fig. 4).

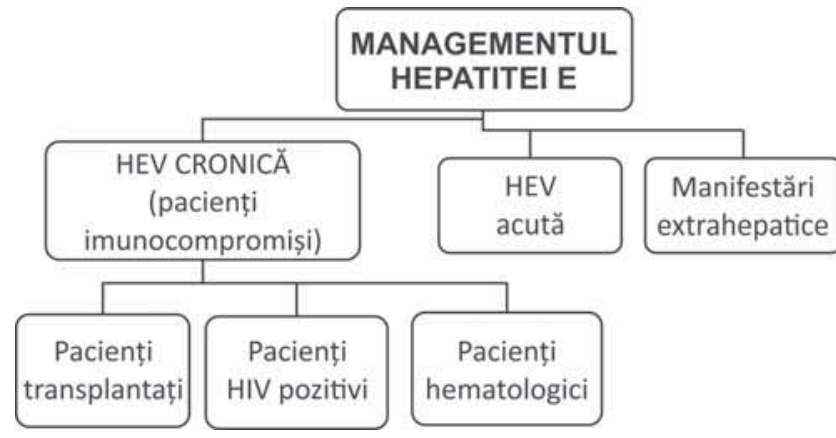

FIGURA 4. Istoria naturală a infecției cu HEV

În plus față de manifestările clasice hepatice, VHE este responsabil pentru tulburări extrahepatice. Acestea includ o serie de sindroame neurologice, leziuni renale, pancreatită şi probleme hematologice (Tabelul 2).
$\mathrm{Au}$ fost descrise simptome neurologice pentru HVE1 şi pentru infecțiile acute şi cronice cu HVE3. Atunci când acest lucru survine, diagnosticul poate fi uşor trecut cu vederea, deoarece tabloul neurologic domină imaginea clinică (10). Manifestările neurologice observate la pacienții cu HVE sunt sindromul Guillain-Barré, paralizia Bell, amiotrofia neuralgică, mielita transversă acută şi meningoencefalita acută (Fig. 4). Într-o analiză retrospectivă a 126 de pacienți cu infecție cu VHE, au fost observate simptome neurologice la 7 pacienți $(5,5 \%)$ incluzând 3 pacienți imunocompetenți cu infecție acută, 3 pacienți cu transplant de organe solide (SOT) şi 1 individ HIV-pozitiv cu infecție cronică.

TABELUL 2. Manifestări extrahepatice în infecția cu VHE

\begin{tabular}{|c|c|c|}
\hline $\begin{array}{l}\text { Pancreatită } \\
\text { acută }\end{array}$ & & \\
\hline Musculoscheletale & $\begin{array}{l}\text { Miozită necrozantă } \\
\text { Piomiozită }\end{array}$ & \\
\hline Hematologice & $\begin{array}{l}\text { Anemia hemolitică } \\
\text { Anemia aplastică } \\
\text { Aplazia pură de celule roșii } \\
\text { Tromocitopenia severă } \\
\text { Sindromul hemofagocitic }\end{array}$ & $\begin{array}{l}\text { Deficit de G6PD } \\
\text { Autoimună }\end{array}$ \\
\hline Renale & $\begin{array}{l}\text { eRFG scăzută } \\
\text { Glomerulonefrită = } \\
\text { Crioglobulinemie }\end{array}$ & $\begin{array}{l}\text { Glomerulonefrită } \\
\text { membranoasă } \\
\text { Glomerulonefrită } \\
\text { membranoproliferativă } \\
\text { Nefropatie IgA } \\
\text { Nefroangioscleroză }\end{array}$ \\
\hline $\begin{array}{l}\text { Altele } \\
\text { imunomediate }\end{array}$ & \begin{tabular}{|l|} 
Tiroidită \\
Miocardită \\
Purpură Henoch-Schönlein \\
Miastenia gravis
\end{tabular} & \\
\hline
\end{tabular}

Recent, sindromul Guillain-Barré asociat $\mathrm{cu}$ miozita necrotizantă a fost descris pentru un pacient cu transplant de ficat. Este interesant faptul că

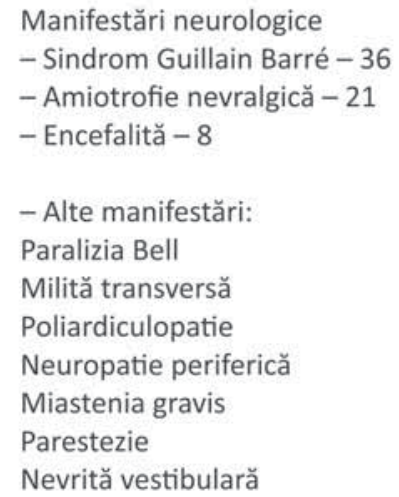

Repartiți geografică

Europa - 63 cazuri

- Belgia

- Franța

- Germania

- Irlanda

- Portugalia

- UK

- Scoția

- Olanda

Asia - 21 cazuri

- Bangladesh

- China

- Hong Kong

- India

- Thailanda

SUA - 1 caz
FIGURA 5. Manifestări neurologice în infecțiile cu HVE 


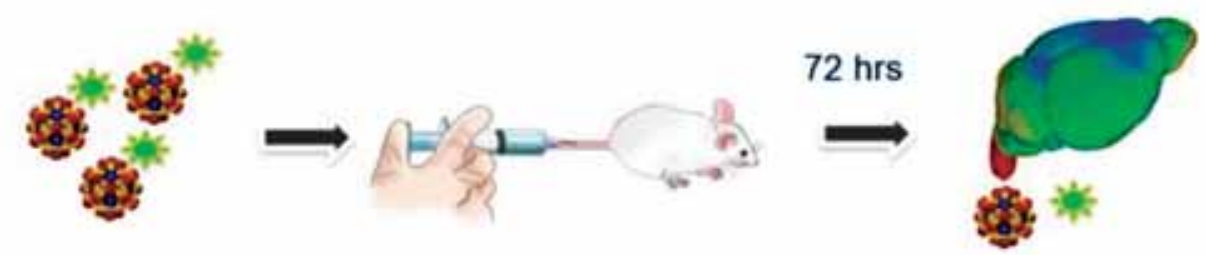

FIGURA 6. VHE trece de bariera hemato-encefalică (Xhou et al J Inf Dis 2017)

ARN-ul VHE în lichidul cefalorahidian (LCR) a fost documentat pentru toți pacienții cu infecție hepatică cronică prezentând sindroame neurologice (10). Secvențele clonale din LCR-ul şi serul unui pacient cu transplant de rinichi şi cu hepatită cronică şi simptome neurologice au demonstrat compartimentarea quasispecie. Acest lucru sugerează că leziunile neurologice asociate HVE pot fi legate de apariția unor variante neurotropice. Mai recent, au fost descrise cazuri de sindrom Guillain-Barré antigangliozid GM1-şi GM2-pozitiv asociate cu infecția cu HVE (11).

Un studiu efectuat în 2017 pe şoareci de laborator a demonstrat că VHE trece de bariera hematoencefalică (Fig. 5).

Funcția renală afectată a fost observată atât la infecțiile HVE acute, cât şi la cele cronice. Ca şi în cazul altor virusuri hepatotrope, infecțiile cu HVE 1 şi 3 pot provoca afecțiuni glomerulare. Au fost observate două modele histologice diferite ale bolii glomerulare: glomerulonefrita membrano-proliferativă şi glomerulonefrita membranoasă. Aceste leziuni la nivel renal au fost observate atât la pacienții imunocompetenţi, precum şi la pacienţii cu transplant de rinichi sau de ficat. Mecanismele fiziopatologice ale leziunilor renale asociate cu HVE sunt incerte, dar crioglobulinemia poate avea un rol important, fiind documentată pentru pacienții cu infecție cronică (12).

Pancreatita acută a fost asociată cu infecția cu HVE1. Cu toate acestea, nu au fost raportate cazuri de pancreatită cu niciunul dintre celelalte genotipuri. Trombocitopenia şi anemia aplastică au fost raportate la pacienți cu infecția acută cu VHE (13).

Numeroase studii din țările în curs de dezvoltare au arătat o creștere a mortalității la femeile gravide care dezvoltă infecție cu virusul hepatitei E. Mortalitatea este de 20 până la $25 \%$ şi apare de obicei în al treilea trimestru de sarcină. Femeile gravide mor din cauza problemelor obstetricale (inclusiv hemo- ragie sau eclampsie) sau dezvoltă insuficiență hepatică fulminantă. Naşterile sunt totuşi frecvente ca şi transmiterea pe verticală la supraviețuitori, care au o morbiditate şi mortalitate neonatale crescute. Mortalitatea în exces în timpul sarcinii cu genotipurile HVE 1 şi 2 este unică, nefiind observată la genotipurile 3 şi 4 (deşi au existat câteva cazuri documentate la femeile gravide) şi nici nu este întâlnită la infecțiile cu alte virusuri hepatotrope.

Cauza excesului de mortalitate maternă la pacientele cu infecție cu virusul hepatitei E este incertă şi a făcut obiectul a numeroase studii şi dezbateri. Sarcina este caracterizată de o stare de toleranță imună maternă față de făt. Activitatea celulelor T este redusă, există o reducere a producției de citokine în primele 20 de săptămâni, predomină răspunsurile Th2. Schimbările în răspunsurile imunologice materne sunt determinate - cel puțin parțial - de schimbările semnificative în profilurile hormonale, cu niveluri crescute de progesteron, estrogen şi gonadotropină corionică umană. Studiile au arătat diferențe semnificative în răspunsurile imunologice şi hormonale la femeile gravide cu insuficiență hepatică fulminantă cauzată de VHE (14). Totodată, studii recente au arătat faptul că în rândul femeilor infectate cu VHE s-au observat încărcături virale mai mari la cele gravide decât la cele care nu erau însărcinate (15).

Pacienții cu afecțiuni hepatice cronice care dezvoltă hepatita $\mathrm{E}$ au un prognostic nesatisfăcător deoarece dezvoltă frecvent insuficiență hepatică acută sau subacută. Într-un studiu efectuat la o cohortă mare de pacienți cu boală hepatică cronică decompensată din India, cei care au avut decompensare din cauza infecției acute a virusului hepatitei $\mathrm{E}$ au prezentat un prognostic semnificativ mai rău decât pacienții care au decompensat ca urmare a unei alte cauze. Mortalitatea pe 12 luni în cohorta cu infecția cu VHE a fost de 70\%. În țările dezvoltate, studii mai mici au arătat, de asemenea, un pro- 
gnostic nesatisfăcător pentru pacienții cu boală hepatică cronică, dar nu este clar cât de des se întâmplă acest lucru, deoarece aceştia nu sunt testați în mod curent pentru a evidenția infecția cu VHE. Cu toate acestea, două noi studii arată că există o relație puternică între decesele cauzate de boala hepatică cronică decompensată şi consumul de carne de porc în țările dezvoltate. Motivul pentru această observație este incert, dar poate fi explicat prin infecția nerecunoscută cu HVE. Studiile pentru a aborda această ipoteză sunt în desfăşurare, iar rezultatele sunt aşteptate cu interes (16).

Incidența HVE la pacienții cu infecție HIV este scăzută, variind de la 0 la 1,3\%. Au fost raportate şi documentate foarte putine cazuri de HVE decelate prin PCR la pacienții seropozitivi, iar în toate cazurile aceştia au fost infectați genotipul 3. Totodată, în literatura de specialitate sunt menţionate cazuri de ciroză hepatică legate de HVE la seropozitivi.

În literatura de specialitate au fost descrise puține cazuri de HVE cronică la pacienții hematologici, la pacienți tratați pentru limfom cu celule $\mathrm{T}$, pacienți cu limfom non-Hodgkin în tratament cu Rituximab, pacienți netratați cu leucemie cu celule păroase, pacienți cu limfopenie T CD4 idiopatică, pacienți cu leucemie cronică mielomonocitară, pacienți cu leucemie limfocitară cronică. Există, totuşi, cazuri de HVE cronică şi posttransplant de celule stem.

Pentru a identifica ARN-ul virusului hepatitei E circulante, pentru a determina genotipul şi numărul de cazuri - inclusiv contextul de transmitere potențială de la animale domestice, peridomestice şi sălbatice -, utilizarea metodelor RT-PCR reprezintă metoda de elecție. Şi investigațiile paraclinice nespecifice sunt utile; astfel, HLG poate indica apariția anemiei şi trombocitopeniei (numeroşi bolnavi cu HVE au fost diagnosticaţi şi cu anemie aplastică), în numeroase cazuri a fost identificată scăderea concentrației de protrombină - sub 50\% în formele clasice de HVE, sub $25 \%$ în formele fulminante. Examenul biochimic indică prezența sindromului de hepatocitoliză (cu creşterea valorilor transaminazelor de peste 10x limita normală, TGP > TGO) şi a sindromului colestatic.

Determinarea concentrației IgG anti-HVE ar putea fi utilă pentru determinarea nivelului care previne în mod sigur HVE după infecții naturale sau administrarea de vaccin în trialuri clinice. Studiul vaccinului a sugerat că o concentrație de anticorpi de 2,5 U/ml a fost de protecție. Protecția IgG nu este specifică. Printr-un vaccin recombinant cu genotip 1, au fost prevenite ambele infecții cu genotipul 1 şi 4, indicând protecția încrucişată împotriva diferitelor genotipuri VHE. Sunt necesare mai multe studii pentru a evalua valoarea clinică a testelor imunoblot IgG şi a testelor de aviditate (17).

La pacienții cu infecție hepatică acută, peak-urile viremiei sunt maxime în timpul perioadei de incubație şi în timpul fazei simptomatice timpurii. ARN-VHE devine nedetectabil în sânge la aproximativ 3 săptămâni după apariţia simptomelor, dar

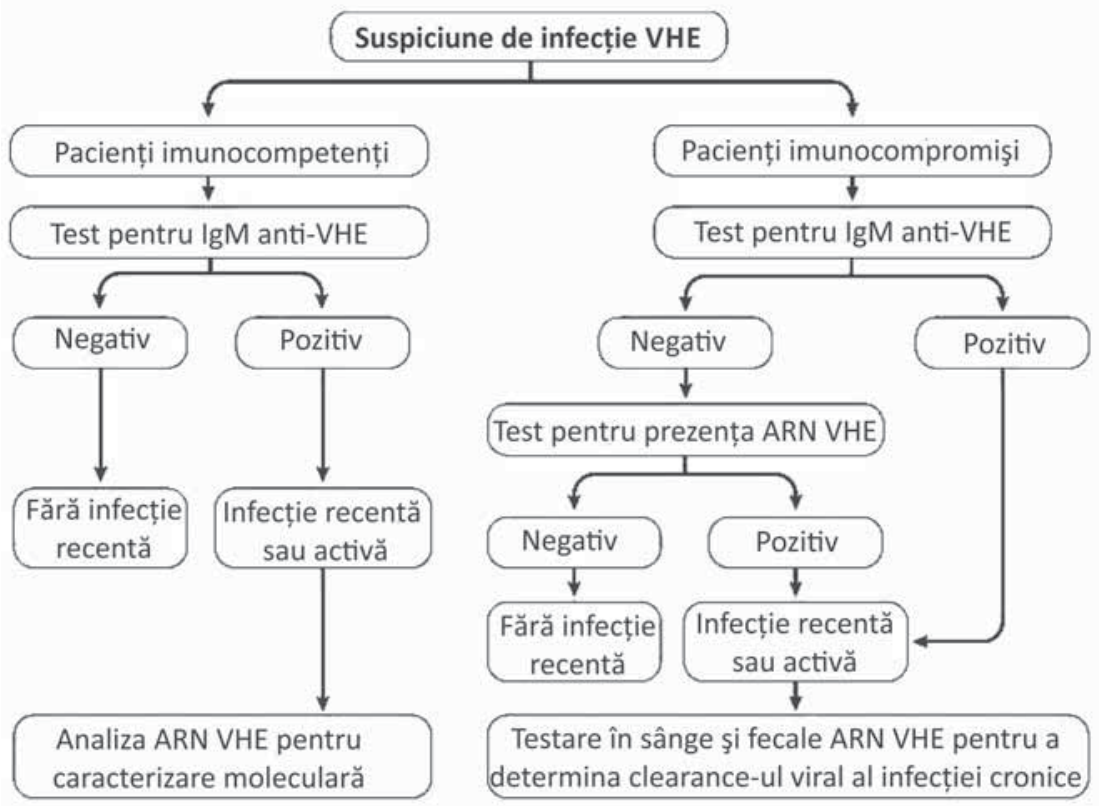

FIGURA 7. Algoritm diagnostic în infecția cu VHE 


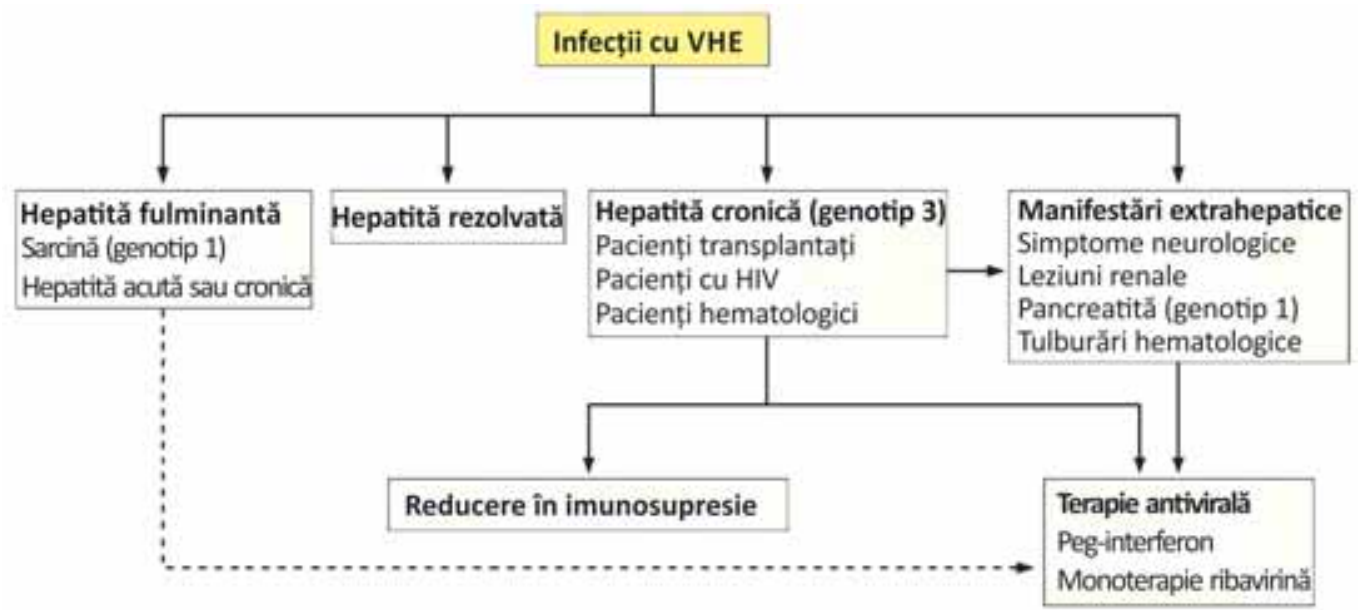

FIGURA 8. Managementul hepatitei $E$

poate fi detectat în fecale timp de încă 2 săptămâni. Totuşi, dacă pacienții sunt testaţi cu întârziere în faza simptomatică a bolii, un rezultat negativ al ARN-ului HVE nu exclude infecția recentă. Concentrațiile serice ale ARN-ului în faza acută au fost cuprinse între 2,1 şi 8,3 copii/ml la pacienții imunocompetenți. $\mathrm{Nu}$ există nicio relaţie între concentrația ARN-VHE în ser şi simptomele clinice.

La pacienții cu transplant de organe solide $\mathrm{cu}$ hepatită acută E, viremia VHE a variat de la 2,7 până la 7,8 copii/ml şi nu a fost asociată cu evoluția spre infecții cronice (18).

Diagnosticul diferențial se face cu alte boli infecțioase: leptospiroză, bruceloză, alte hepatite virale (HAV, HCV, HBV), toxoplasmoză şi cu afecțiuni non-infecțioase precum hepatită toxică medicamentoasă, hepatită alcoolică, hepatită toxică (apărută după consumul de ciuperci otrăvitoare), hepatită autoimună, angiocolită, neoplasm hepatic, metastaze hepatice, deficitul de alfa1-antitripsină, sindromul Budd-Chiari, hemocromatoză, boala Wilson.

Managementul hepatitei $\mathbf{E}$ implică atât terapia pacienților cronici sau imunodeprimați, cât şi terapia infecțiilor severe acute cu VHE şi a manifestărilor extrahepatice (Fig. 7).

Tratamentul farmacologic al infecției cu HVE include Peg-Inf, ribavirină şi, de asemenea, cei mai noi agenți DAA. Un studiu multicentric efectuat în Franța pe 59 de pacienți cu transplant de organe solide şi cu HVE cronică arată SVR de $85 \%$ la finalul terapiei cu ribavirină. Ribavirina inhibă replicarea VHE prin epuizarea canalelor GTP (Fig. 8).

Un tratament alternativ la ribavirină pentru pacienții transplantați cu HVE este monoterapia cu Peg-IFN. Sofosbuvir inhibă replicarea VHB în vitro, având un efect potențiator în combinație cu ribavirina.

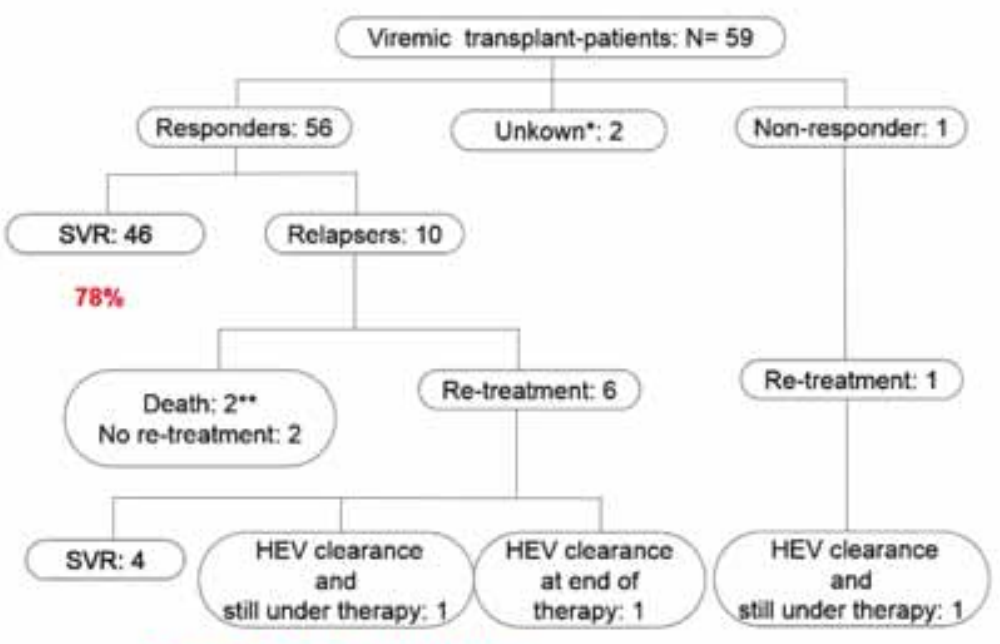




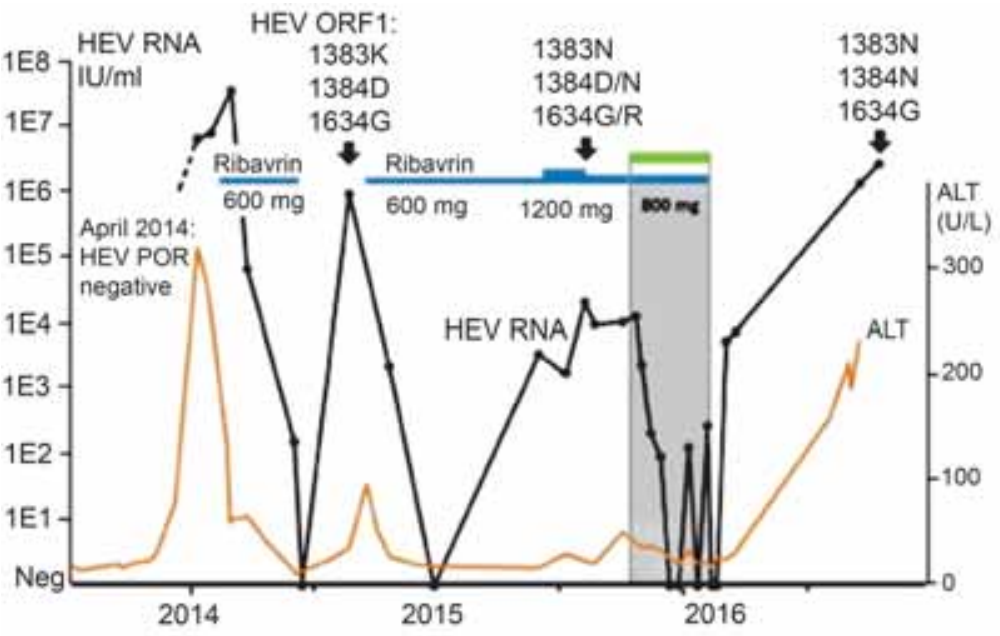

FIGURA 10. Ratele de răspuns virologic la tratament în cazul unor pacienți transplantați (Van der Valk et al.)

Evoluția hepatitei virale $\mathbf{E}$ poate fi severă şi fulminantă din cauza insuficienței hepatice acute. Importanţa prevenirii şi controlului acestei infecții este mult mai justificată pentru reducerea mortalității generale şi a mortalităţii materno-fetale. O rată a mortalității de $27 \%$ a fost raportată la pacienţii cu boală hepatică cronică preexistentă (2).

În conformitate cu conceptul actual, eforturile în domeniul medicinii umane şi al sănătăţii publice ar trebui să fie legate de măsuri suplimentare privind siguranța alimentară şi mediul, cum ar fi identificarea genotipurilor 3 şi 4 ale virusului hepatitei $E$ în diferite produse alimentare de porc şi fructe de mare, să evalueze incidența acestor genotipuri care ar putea fi responsabile pentru majoritatea cazurilor de boală din Europa. De asemenea, este necesar să se monitorizeze circulaţia HVE în apele de suprafață ale faunei sălbatice (3).
Prevenirea HVE se bazează pe menținerea apei potabile, condițiile adecvate de igienă, respectarea regulilor de igienă personală şi evitarea utilizării peştelui negătit corespunzător, a nucilor şi fructelor neprăjite, mai ales în țările endemice (4). Un vaccin recombinat aprobat şi efectuat în China în 2011 deschide perspective pentru aceste măsuri de prevenire specifice în zonele identificate ca fiind expuse riscului, pentru a limita consecințele infecției cu virusul hepatitei E în populaţia generală şi grupurile expuse (5).

Sunt necesare criterii noi de asigurare a securității sângelui de la donatori din populația generală, pentru a limita riscul de infecție cu virusul hepatitei E în populația generală şi pentru diferite categorii de persoane expuse riscului. 